\title{
Improving The Ability Of Writing Art Criticism Through Blended Learning
}

\author{
Hadjar Pamadhi ${ }^{1}$, Heri Maria Zulfiati ${ }^{2}$ \\ hpamadhi@uny.ac.id ${ }^{1}$,heri.maria@ustjogja.ac.id ${ }^{2}$ \\ Universitas Negeri Yogyakarta, Indonesia ${ }^{1}$, \\ Universitas Sarjanawiyata Tamansiswa, Yogyakarta, Indonesia ${ }^{2}$
}

\begin{abstract}
Writing art criticism requires cognitive insights pertaining to artwork, art history, curatorial writing and art criticism, and evaluation of artwork. Face-to-face lessons take less than 1650 minutes to explore materials. Therefore, it is necessary to extend learning strategies and approaches using integrated learning methods. Lecturers write lesson plans, reference materials, assignments and class discussions through weblogs, face-to-face teaching activities with a combination of Internet access, writing practice and interpretation of works. The results of blended learning show the students' improvement in terms of real insights, curatorial writings, and art criticism positively.
\end{abstract}

Keywords: Lesson Plans, Weblog, Blended Learning

\section{Introduction}

The Department of Fine Arts Education, Faculty of Languages and Arts at the Yogyakarta State University educate prospective teachers. One of the tasks of a prospective teacher is to master the principles of teaching arts for children, giving and delivering evaluation and critique of the work to the students [1]The learning process is more traditional, the lecturer provides lectures in the classroom through face-to-face interactions (F2F). In the face-to-face learning strategy, the graduates are less creative in dealing with factual issues. Several efforts have been made to develop in-class learning processes through which a tendency to face the college emerges. The results of Sari \& Purtadi's study [2] refer to the face-to-face learning strategy that has weaknesses because it is abstract and relatively passive. Regarding the case of lecture criticism on arts, students feel dictated and do not dare to ask questions in detail, because it depends on the hearing capture when the lecturer presents the materials. As the documents contain abstract concepts, students carelessly do the audio recording and graphics resulting in a state of more unidirectional lectures. Lecturer-student interactions rarely take place, and the learning atmosphere seems quietly interactive.

The art criticism has a composition of $60 \%$ on studying the art development in Indonesian market of arts, and $40 \%$ learns to interpret the meaning of skills and write a curation and criticism. The aims of this subject are to strengthen the concept of creation. Students experiencing boredom are unable to provide a factual example. [3] highlights the problem related to the declined quality of artworks of Indonesian artists due to acceptance and offer of painting orders (Ngijon - Javanese). This kind of discussion does not occur in the classroom. On the other hand, the lecturers' examples static depending wholly on the old literature resulting in inconsistencies with the new atmosphere. The art criticism raises the essential issues of artwork's extensive and profound quality. The course materials are open because students follow the development of arts in Indonesia and overseas. The event of excellent skills in Indonesia, especially in the city of Yogyakarta, marks the current trends of art exhibitions almost twice a week. Presentations are based on the digital technology and manuals on social ideology and antagonisms, for example, the face-to-face ideology of art criticism containing an objective representation of theories that become the subject of paintings [4]. Art critics must master the process of creation called the description of the nature of the artwork. The profound concept of a work of art is to understand the ideology, as well as the life of the invention of art by the artist.

In general, the subject of art criticism contains knowledge of a representation of the creation of artwork, the technique of interpretation of the artwork, written and oral presentations. As the materials are widely and deeply designed, the lecturer chooses a blended learning strategy. Elements are divided into stages of art insights, interpretive theory, oral and graphic writing and presentations. The students' oral presentation conducts guided class discussions on the basis of problem-based learning, whereas students attend field studies in groups and collaborative discussions. Graphics performance is a collection of papers.

Prior to presenting, students master the theory of interpretation and metacognitive analysis as well as metanalysis. This theory is to explore the process of creating artwork and explain the process of objectivization, object interpretation, subjectivization, symbolization, creation, and expression. Metacognition is meant to apply cognitive knowledge that metaphysically views the object as a source of inspiration for the nature of the art treasure. Metanalysis is the process of artists analyzing the purpose ontologically and axiologically so as to determine the point of the magnitude of the aesthetics for the subject of this work later. This meta-analysis will produce conceptual materials, as well as image thinking (picture-based thinking). 


\section{Method}

The material representation of this work of arts requires various examples of an artist to see, observe and understand how objects are chosen based on the aesthetic perception of the artist. The material found in the interpretation of the work is developed into the object symbols.

The syllabus is described, as follows:

"This course focuses on discussing art and its development through writing art criticism formally. The designed materials are based on the educational and journalistic criticism to develop art appreciation in schools. Students are asked to analyze and write articles concerning theories of curatorial writing and art criticism and presented verbally or non-verbally at the appointed time " [5]

The lecture objectives can be used to develop the lecture syllabus, as follows:

1. Description of artistic representation, meaning, function and the position of art criticism as a science and knowledge

2. The story of art space and time in art

3. The technique of writing for art curation and art criticism

4. The theory of analysis of the art development in four pillars of power

5. Oral presentation and written art creation and issues of appreciation

A learning flow scheme is created, as follows:

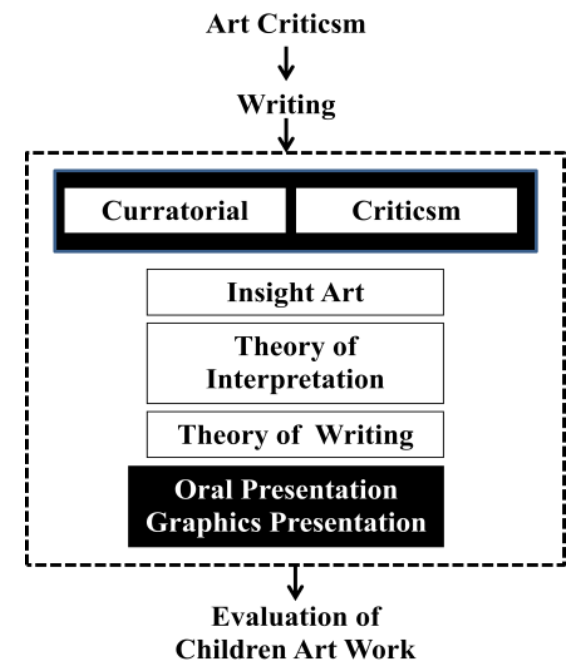

Fig. 1.: Art criticism learning based on the discussion of materials

\section{Result}

Art criticism course is one of the lectures that gains more emphases on the practice of writing for works of art as viewed from the ideology, media, the principle of creation and the concept and existence in the world of art. The primary function of art criticism is to bridge the perception and appreciation of works of art, between artists, practices, and art connoisseurs. The writing of art criticisms expresses oral and graphic presentations that attempt to explore and analyze course materials expected to foster artists and connoisseurs to communicate through work of art. From this scope of criticism, the teaching materials are dynamic because they contain standard elements and dynamic objectives. The conventional teaching materials derive from the existing theory, but the active teaching materials are contemporary in nature. For example, exhibitions held at several Art Houses and Gallery showcase various types of artwork, some of which discuss modern theories as well, but other commercial presentations also deal with the sale of artworks. The task of the student is to choose the work that coincides with the interests of his or her studies. The Art Criticism course is divided into several approaches and methods of learning, i.e., F2F (face to face) presentation by displaying Powerpoint (PPT) slides, internet access and discussion including a focus group discussion. F2F (face to face) introduction encourages lecturers to deliver lectures by giving questions and answering them as well. In this case, the lecturer prepares the material, uploads on the Weblog such as bit.ly/pamadhi17. The Weblog contains one-semester lecture, reference, assignment. 
Table 1. The framework of the Learning Approach

\begin{tabular}{|c|c|c|}
\hline No & Material & Approach \\
\hline 1. & Representation & F2F, PPT, weblog \\
\hline 2. & $\begin{array}{l}\text { Space and Time in Art } \\
\text { representation }\end{array}$ & $\begin{array}{l}\text { FGD, F2F, } \\
\text { weblog }\end{array}$ \\
\hline 3. & $\begin{array}{l}\text { Techniques of writing } \\
\text { curation and art } \\
\text { criticism }\end{array}$ & $\begin{array}{l}\text { PPT, Consult, } \\
\text { weblog, } \\
\text { Discussion }\end{array}$ \\
\hline 4. & $\begin{array}{l}\text { Analytical theories of } \\
\text { art development }\end{array}$ & $\begin{array}{l}\text { PPT, Weblog, } \\
\text { Field Study }\end{array}$ \\
\hline 5. & $\begin{array}{l}\text { Oral and written } \\
\text { presentations }\end{array}$ & $\begin{array}{l}\text { PPT, Weblog, } \\
\text { FGD }\end{array}$ \\
\hline
\end{tabular}

The course materials on the representation of artworks are taken from books and concepts of art education. The articles encompass thinking patterns of the creation such as objectification, subjectivization, and symbolization, visualization and expression.

Representation: Re-emergence of the object for the observation of the artist is in line with the subject of artwork. This representation goes through a complicated process, ranging from objectification (determining the most beautiful point of an object) and symbolization that is changed into the subject of new artwork. This process undergoes reduction, shrinking of forms, ideas and its development into the question of [6]Teaching materials on representation can be described as follows:

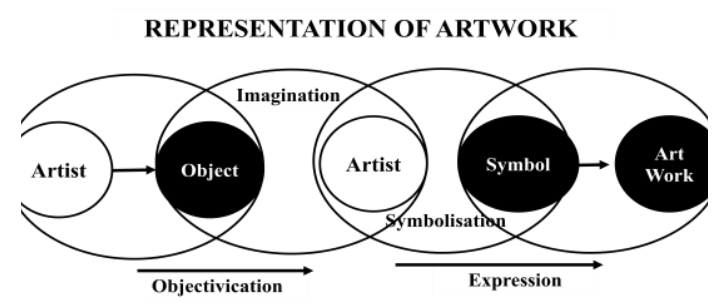

Fig. 2. Description of artwork

An artist is a person who has freedom in determining objects. The object itself consists of two essential parts: object as a material and object as a formal representation. The objective of the study is the material functioning as the natural object that will be explored by an artist and the artist determines the symbolization. Some villages and traditional societies keep maintaining an artistic form that becomes the source of the idea of creation and development using the F2F approach, PPT, References, the Weblog as main references and the findings are classlevel discussions.

Table 2: The Blueprint of Blended learning

\begin{tabular}{lll}
\hline No. & Material & Approach \\
\hline 1. & Objectification: & $\bullet$ Weblog, \\
& $\bullet$ Object focus & $\bullet$ Access the \\
& $\bullet$ Aesthetic of the & \multicolumn{1}{c}{ internet } \\
& object & $\bullet$ PPT \\
& $\bullet$ Theory of & $\bullet$ Reference \\
& perception & \\
& $\bullet$ History of the & \\
& aesthetical object & \\
\hline 2. & Object & $\bullet$ Discussion \\
& $\bullet$ Material: & $\bullet$ Reference \\
& physical object & $\bullet$ Access the internet \\
& $\bullet$ Formal Object & \\
\hline 3. & Artist & $\bullet$ Weblog, \\
\hline
\end{tabular}




\begin{tabular}{|c|c|c|}
\hline & $\begin{array}{l}\text { - Background of } \\
\text { the artist } \\
\text { - Goal of } \\
\text { presentation } \\
\text { - Principle of } \\
\text { representation } \\
\text { - The style of an } \\
\text { artist's creation } \\
\text { - Artist's way of } \\
\text { life }\end{array}$ & $\begin{array}{l}\text { - Access the } \\
\text { internet } \\
\text { - PPT } \\
\text { - Reference } \\
\text { - Observation of } \\
\text { Artist doing an } \\
\text { artwork }\end{array}$ \\
\hline 4. & $\begin{array}{l}\text { Imagination } \\
\text { - Object or formal } \\
\text { material used in } \\
\text { experimenting } \\
\text { - Social responses }\end{array}$ & $\begin{array}{l}\text { - Weblog, } \\
\text { - } \text { Access } \\
\text { internet } \\
\text { - } \quad \text { PPT } \\
\text { - } \quad \text { Reference } \\
\end{array}$ \\
\hline 5. & Objectification & $\begin{array}{l}\text { - } \text { Weblog, } \\
\text { - Internet Access } \\
\text { - } \text { PPT } \\
\text { - } \text { Reference } \\
\end{array}$ \\
\hline 6. & Symbolisation & $\begin{array}{l}\text { - Weblog, } \\
\text { - Access } \\
\text { internet } \\
\text { - } \text { PPT } \\
\text { - Reference } \\
\text { - } \text { F2F } \\
\end{array}$ \\
\hline 7. & Art Work & $\begin{array}{l}\text { Field Study } \\
\text { - Weblog, } \\
\text { - Access } \\
\text { internet } \\
\text { - Reference } \\
\end{array}$ \\
\hline 8. & $\begin{array}{l}\text { Presentation } \\
\text { - Oral } \\
\text { - Graphics }\end{array}$ & $\begin{array}{l}\text { - Access the } \\
\text { internet } \\
\text { - PPT } \\
\text { - Reference }\end{array}$ \\
\hline
\end{tabular}

- Structuring the Art Criticism course above, the approach strategy may change over time under certain conditions. The first step is that the lecturer uses the F2F approach based on one of the discussion materials: 'The influence of experience on the object selection' and its influence on how to determine the focus discussion defined as the 'process of determining the aesthetic object' for an object of observation. Broadly speaking, this step goes into the interpretation category of artist's behaviors. The 'Space and Time' course materials highlight the development of space and time meaning based on the history of the artistic creation of Plato and Andi Warhol. It means that beauty has its object and form for expressing artworks. Historical searches on how to determine the object of the beauty, the form of the social problem through the discussion are preceded by the lecturer to explain the outline of F2F (face-to-face) approach. Some words and objects deliberately deleted the course on the internet to activate students' activities From this activity, students are expected to get the internet access to the meaning and concept of space and time based on the reference: articles on the Space and Time. The lecturer will design the outline of the meaning with students. The lecturers' intervention on the results of discussions determines the meaning of Space and Time based on the experts' opinions of metanalysis. By doing so, lecturers save time (effectiveness of the discussion time). This problem-based learning usually takes a long time, because it sums up opinions. This step is implicitly developed for writing a curation of a painting. The presentation of curation and criticism materials begins with asking questions for discussions among students who create in-class small group discussions. The lecturer shows some curatorial articles that are deemed eligible and ineligible. The strategy used is a comparative study of several papers (including the curatorial and art criticism). The student's task is to compare the two documents and summarize the meaning and characteristics of curation and art criticism styles.

The discussion is open to dismiss the problem continued with a particular focus, which is handled in a small group discussion. Each group makes a summary of meaning and characteristic of writing. In this case, the lecturer directs the technique and style of the curated writing curl. The notion of curation can approximately be completed in the eighth week ended with formative tests and the writing of curatorial works of art. Students are required to conduct field studies by visiting one of the exhibitions and preserving to be curators of artwork. The results are sent directly to the provided Weblog. 
- In the upcoming meeting, the formative test results are matched with mid-semester exams by discussing the curatorial artwork and, in this sense, three curatorial articles are selected at random. In accordance with the principle of formative tests, the students who underperform in writing are given a chance to improve their performance, until their articles are accepted. Subsequent course material is an analysis of the development of art in which intended students gain knowledge about the steps, and how to interpret the work of arts. Two simple theories about Charles Sanders's semiotics and hermeneutics are given through the F2F method; this material is explored and developed through internet access of hermeneutics articles. The pause time is given to convey the theory, followed by summarizing the argument. The first and second weeks proceed with analysis practices of semiotics and hermeneutics. The knowledge about semiotics and hermeneutics is expected to strengthen the interpretation of artworks at the time of thesis analysis.

Semiotics aims to read the meaning of the work through the understanding of visual elements, and hermeneutics to know and describe the definition based on the historical study and trace. The next discussion is to incorporate the results of semiotics reading into the concept of aesthetic form through Monroe Beardsley's theory. Three reviews of the whole work through the view of unity, intensity, and complexity are worth considering. The final result of the Art Criticism writing course is an oral and written presentation. This activity is synchronized with the final exam of the semester. Therefore, students are expected to do the business in two weeks before the end of the semester. Writing materials are taken from direct observation at a painting exhibition (art) along with photograph and catalog of the show. The next step is to consult the title as well as the choice of an analysis model of the work. In this case, students are allowed to hold informal discussions between friends and early presentations. The assessment of final task in this lecture is undertaken in the form of written accounts through the discussion or question and after declaring the completion students upload them in accordance with the weblog address. The presentation of assessment is in the form of an exciting title, abstract writing, style of writing, the suitability of photos with writing, giving reasons, how to explore works using an interpretation model and conclusion of writing. The final project activity as this exam will be re-read by the lecturer after being uploaded on the Weblog. Art criticism learning problems include the extent of subject matter, the demand for writing skills through interpretation and metanalysis - metacognition. This problem is solved through a blended learning strategy. The term blended learning (BL) is actually based on an integrated method and collaboration between students and lecturers. The term integrated means a union with alternating methods based on deficiencies in face-to-face lectures. If hindrances occur, lecturers compare and choose one of the methods that can generate learning gifts [8]The concept of blended learning adapts the development of the creation of artwork, the material of artistic insight (works, creation ideology and media of art) and interpretation of works. The word blend means a mixture; for example:

$$
\begin{gathered}
\mathrm{A}+\mathrm{B}=\mathrm{C}, \text { or } \\
\mathrm{A}+\mathrm{B}=\mathrm{AB}, \text { or } \\
\mathrm{A}+\mathrm{B}=\mathrm{Ab},
\end{gathered}
$$

this mixing becomes the newest method, or simply alternately executes the method or amplifies one method with a small mixed-method basis. Clifford (2016) defines BL as the phenomenon of blended learning that has its roots in online learning and represents a fundamental shift in instruction that has the potential to be optimized for the student. Although schools have been using computers and technology for some time, they have blended them out of instruction that they have some elements of control over their learning [9]. Its implementation in the F2F task is developed into a four-strategy approaches. The lecturer motivates students to look at the meaning and the characteristic of the art (paintings) when the students to visit the exhibition as the task requested. If described in the scheme, the step elaborative, as follows

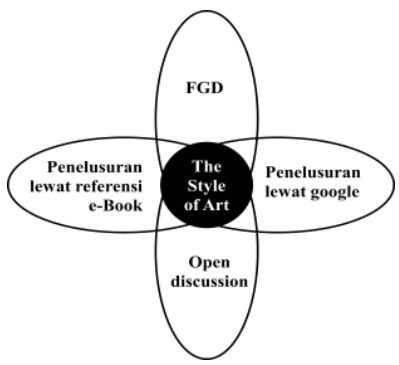

Fig. 3.: Blended Learning that solves the task in terms of the style of painting 
BL will be successful if the students' active participation can be developed with the concentric arch model, whereas the main problem is placed as a talking center. Lecturers write sentences or keywords and develop the references as to show the essence of meaning. Some internet sites will give different views and even meanings; in this case, the lecturers should be able to find the substance or the essence through this search in order to map out the time or period of understanding. In accordance with the concept of the year of creation, the theme and title of a work of art will show variations of meanings. This procedure will provide an overview of the development of meaning based on the year or era of creation. For example, Dullah's Realism will refer to color, the shape or the figure, and characteristic of the theme. The development of realism has now changed objects, from material objects to the idea of developing the art of realism into a formal object represented into the world of art installation or happening art.

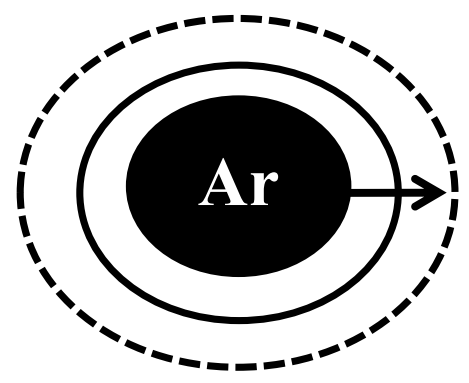

Fig. 4.: A Model of Concentric Arch Blended Learning

By the semester, students are required to write criticisms of artwork at an art exhibition along with BL conducted by students to complete the writing assignment. This process can be unordered as shown in the scheme below, but the existing elements can be done in a mixture of interests. Thus, the task given by the lecturer can be done earlier. If students memorize materials in the lesson plan that have been uploaded through the Weblog in advance, they can prepare themselves. This constellation is more like a consultation that can be handled more than one in the face-to-face lecture. This aims to make the acquisition of writing ability perfectly valid. It is expected that students do the exercises repeatedly so that the writing assessment is done through the presentation, and students must prepare the script and the materials in the form of Powerpoint program. After BL activities are done, it is necessary to evaluate them. The findings of these evaluations are psychologically at first perceived by students in confusion. Some students feel stressed because the activities run fast. Students using android media to communicate explore helpfully. Students can carry out the operations by reading the lecture plan that has been uploaded, but most students do not dare to read and discuss. This possibility is a habit of previous learning that depends on the presence of lecturers. Changes in the traditional learning system strongly depend on the ability of lecturers to present materials, and lecturers play a single role as a disseminator of information. Unlike this learning system, in the BL model, the lecturer becomes a motivator because he or she always motivates students to access the internet. The upcoming development of students will be reduced by the learning model that depends on the lecturer. Some students admit that after applying the BL model, learning independence is getting higher. Broadly speaking, students' abilities improve after the implementation of BL model, as described below. Students experiencing BL model feel free to pursue knowledge from outside the lecture. There are different descriptions and contents caused by technological developments. Technology leading to new findings have the same principles and concepts. Students' creativity will begin to evolve beyond the course hours that encourage the valuable development of new knowledge. Students relate the theories that have been studied to the work of artists written in the art criticism, and the BL model turns out to be more comfortable.

The BL model gives students the ability to manage themselves as a self-regulated learning style to determine their ultimate goals. They are able to set the speed of learning based on a self-reflection and identify the effectiveness of learning approaches (i.e., having high levels of meta-cognition), tend to view learning tasks as intrinsically interesting as possible because they have high levels of self-efficacy, and engage in and persist with learning behaviors that maximize the degree to which learning occurs (Marcus Credé, A meta-analytic review of the Motivated Strategies for Learning Questionnaire [11].

- Some positive findings show that students enjoy learning in the BL atmosphere. They have freedom to open the site of artists (history), articles of art-making methods, and theoretical knowledge. By reading the artist's history, and the history of artwork creation, students can conclude the concept of creation or the background of the creation of artwork. In addition, the objectification determines the point in which the magnitude of aesthetics of art is not encountered during the formal learning (lectures). When artists express their ideas, students can grasp the ideas that exist in the artwork and imitate the curatorial curatorial style. Multiple advantages are used to develop the principle of writing. Psychological effects of blended learning on students' behaviors are a sense of self-reliance and free time to open useful sites. Curiosity on the art world is increasingly high to find out the flow and techniques 
used to create ideas and the background of the creation of artwork. The BL model is increasingly effective for students to learn in the context of an F2F model satisfactorily.

\section{Conclusion}

Blended Learning (BL) provides a direct and indirect effect on the development of students' learning to write art criticism. The immediate impact is that students acquire knowledge practically when they write the idea of curation and criticism of artwork. In practice, BL has a distinctive style of writing so it can help students understand the artwork easily. Some articles, curatorial examples, and useful art criticisms add to the knowledge that lecturers do not have time to deliver lectures in face-to-face courses.

\section{References}

[1] H. Samadhi, Pendidikan Seni: Hakikat Kurikulum Pendidikan Seni, Habitus Seni dan Pengajaran Seni Untuk Anak. Yogyakarta: SUNY Press, 2012.

[2] S. Permana Sari, Rr. Lis \& Portage, "Pembelajaran Tematik Untuk Mata Kuliah Kimia Dasar sebagai Model Pembelajaran Berbasis Masalah," Cakrawala Pendidik., vol. 3, 2010.

[3] J. Smiers, Art Under Pressure: Promoting Cultural Diversirty in the Age of Globalization. London: Zed Book, 2003.

[4 S. K. Lengger, Feeling and Form. USA, 1955.

[5] H. Pamadhi, Implementation of Course Plan for Writing Art Criticism. Yogyakarta: Department of Arts Education, 2017.

[6] R. J. Belton, The Elements of Art, Department of Fine Arts, Okanagan University College Art History: A Preliminary Handbook. Canada, 1978.

[7] The Liang Gie, Filsafat Seni Sebuah Pengantar. Yogyakarta: PUBIB, 2005.

[8] J. . Heron, The Chemistry Classroom Formulas For Successfull Teaching. Washington, DC: American Chemical Society. 